\title{
Against the fanaticism of forces: Kant's critique of Herder's Spinozism
}

\author{
Beth Lord
}

One of the many puzzling features of Kant's Opus Postumum - the unpublished papers and fragments he was working on up to his death - is his frequent invocation of Spinoza. These references, found mostly in the very late sections of the text, are particularly striking given the content of its earlier sections. ${ }^{1}$ In 'Übergang 1-14' (labelled 'The Ether Proofs' in the English translation), written in 1799, Kant argues for a single dynamical continuum, the ether (also called caloric), that is the material of all appearances. Ether is posited a priori as the single object of perception whose moving forces provide the material for all bodies, and enable the subject to perceive things in space and time. This 'universally distributed, all-penetrating world-material' originally fills space and time with forces, making experience possible in general. ${ }^{2}$ Ether is therefore the material condition of experience, or 'hypostatized' space. The unity of experience demands that this single, space-filling continuum of forces be posited a priori to exist, not hypothetically, but actually.

Kant had long held a dynamical theory of matter and had argued that matter, understood under the principles of natural science set out in the first Critique, is reducible to the interaction of fundamental forces. ${ }^{3}$ The concept of ether is, however, a significant development of that view. It is envisioned as the original, primary matter, which need not appeal to any ground outside itself for its being or subsistence. It contains the material for all possible experience, but is not an ideal sum-total of all possibilities. It is the unified origin of appearance in general, but does not transcend appearances as a supersensible cause. Ether explains the possibility of affection without recourse to noumena or rational ideas, perhaps providing a preliminary response to one of the cliffhangers of the first Critique: 'the manifold, to be intuited, must be given prior to the synthesis of understanding, and independently of it. How this takes place, remains here undetermined. ${ }^{4}$

There is considerable debate about what Kant's ether is and what it entails for transcendental idealism, but entering into that debate is not the purpose of this paper. ${ }^{5}$ Here, I focus on the following questions. Given his apparent argument in the Opus Postumum for the unity of matter and experience in a unique, original, and self-active substance, how are we to interpret Kant's references to Spinoza? Is he admitting an affinity between his own concept of the ether and Spinoza's concept of substance mediated, perhaps, by the idea of a single nature animated by a world-soul that had so recently emerged from Naturphilosophie?

I will argue that Kant's references to Spinoza in the Opus Postumum are, in fact, references to the Spinozism of Johann Gottfried Herder. Throughout the 1780s, Herder had developed a teleological Spinozism which posits a universe generated from a single organic force with divine attributes of a purposive will. In naming Spinoza, Kant signals that his repudiation of Herder's Spinozism, which had been elaborated in the Critique of Judgment, is relevant to the subject-matter of the Opus Postumum. While Kant allows Herder, and Naturphilosophie, that the material world and spatio-temporal experience are made possible by forces, he is not prepared to concede that organisms, human freedom, or God are reducible to force. To maintain 
the integrity of transcendental idealism, Kant must argue for 'an immaterial principle' which is demonstrably external to the world of forces, which gives purposive unity to nature and moral purposes to human beings. ${ }^{6}$ It is precisely because Kant comes so close to Herder's Spinozism in this late text that he must so strongly reject it.

I will first set out Herder's teleological Spinozism, briefly showing how Herder makes use of a universal concept of organic force to explain nature, God, and humanity as aspects of a single material universe. I will then look at Kant's critique of Herder's Spinozism in the Critique of Judgment, suggesting that Kant's major objection is to the notion that force could cause purposive effects immanently and non-intentionally. I will finish by returning to the Opus Postumum, to argue that Kant's critique of Herder's Spinozism provides the context for his remarks on Spinoza there.

\section{Herder's teleological Spinozism}

Kant's critique of Herder emerges from the pantheism controversy, the rapid exchange of texts in the mid-1780s sparked by Friedrich Heinrich Jacobi's remarks on Lessing's supposed Spinozism. The debate was not really about Spinoza, but about whether naturalistic science made faith impossible. Jacobi argued that it did, and therefore that an intuitive faith had to be rescued from philosophers who, if they propounded any kind of naturalism, ended up in Spinozistic atheism. Others, like Mendelssohn and Herder, argued that, on the contrary, naturalism and even Spinozism were compatible with faith. One result of the controversy was that it finally became acceptable to publish on Spinoza in Germany, and that a number of interpretations of Spinoza entered into circulation. By far the most influential was Jacobi's own Concerning the Doctrine of Spinoza, the book that had started the controversy in the first place. Jacobi's interpretation of Spinoza was the major - perhaps only - source of Kant's understanding of Spinoza. Regrettably, Kant probably never read Spinoza's texts. $^{7}$

His student Herder, however, did, and did so enthusiastically. From his earliest writings, he had been developing a Spinozistic vitalism to which Kant was increasingly antagonistic. One of Kant's most devoted and best-liked students in the 1760s, Herder's fusion of theism and naturalism, and his assertion of the unity of nature and reason through a fundamental organic force, were increasingly distasteful to Kant. In texts of the 1770s, Herder offered a naturalistic account of the origin of reason, bound up with a monistic conception of a single universe encompassing both physical and mental phenomena. The divine and supersensible were part of this universe, God being equivalent to the immanent vital force powering change and generation. For Herder, as for Spinoza, God is Nature, and man is part of nature.

These ideas were applied on a universal scale in Herder's 1784-7 Ideas for a Philosophy of the History of Mankind. ${ }^{8}$ In Ideas Herder blends anthropology, history, and natural science to put forward a view of the universe as an organic whole organized by forces. Organic forces are responsible for the generation of all natural phenomena, including human minds and spiritual potential, through the organization of matter by organic form. The primary characteristic of human organic form is not reason, but erect posture, the physiological condition for higher brain functions. Our physical organization determines all that is specifically human: reason, freedom, 
culture, and our directedness towards our highest potentiality or 'Humanität'. Humanität includes peaceful society, organized religion, and the understanding of divine providence, the achievement of which represents both humanity and the universe at their most highly organized. Through the purposeful organization of each living being, the universe is organized to progress towards the perfection of its organic form as a whole, through the realization of Humanität.

Organic form distinguishes an individual as a member of a species, determines its physical organization, and directs it towards the ultimate goal of the universe in its own species-specific way. But since organic form determines matter as a member of a species in general, it must leave very much undetermined at the individual level. What, then, accounts for the infinite variety in nature and generates particular differences between individuals? Herder hints at the worry to which Kant will give full expression in the Critique of Judgment: nature might be so diverse that it exceeds our capacity to understand, and foils our systems of classification. Herder's solution to this problem is to equate organic force with the divine mind, and to yoke both to a Spinozistic principle of unity. Since the divine mind 'has everywhere combined the greatest possible multiplicity with unity', we need not be concerned that individual differences will disrupt our understanding. ${ }^{9}$ Divine organic force gives nature its unity and order, which are revealed to us through our experience of natural forces. Empirical science is a sure route to understanding nature and God truly, and we need not worry that individual differences may exceed our grasp. Indeed, individual differences are part of the divine mind's teleological strategy. Through a process of reciprocal determination between organic form and specific instantiation, individual differences cause organic forms to progress towards nature's universal goal. Particular things find their complete determination in the process of their development, the always-unfinished march towards perfection. The teleological end-point is the perfectly organized universe in which every individual is completely determined and 'finished', its place in the perfect organism assured.

Although Ideas has Spinozistic overtones, Herder's Spinozism was only made explicit in his 1787 book God: Some Conversations. ${ }^{10}$ Taking as its starting point the debate that characterized the pantheism controversy, Herder's God argues that Spinozism brings Christianity and naturalism together in one system. The key to their reconciliation lies in the concept of organic force, which, Herder says, is how Spinoza ought to have understood 'God or Nature'. Here we need to note a peculiar point about Herder's interpretation of Spinoza. Herder rightly understands Spinoza's God to be an active power rather than a static being. But he argues that Spinoza's failure to grasp the dynamic nature of matter led him to explain physical beings through inert extension, to distinguish matter from minds, and to insist on the absolute distinction of the attributes from one another. ${ }^{11}$ Herder takes these to be major problems, because they disrupt his vision of a single universe organized exclusively by organic force. He thinks that Spinoza ought to have rejected the notion of 'infinite attributes' altogether, and conceived God as producing all of reality through one single attribute of 'force'. The irony is that Spinoza conceives every attribute as dynamic: the attribute of extension is not conceived as inert matter, but as infinite relations of motion and rest. Herder's rush to impose his own vitalism onto Spinoza's universe blinds him to the dynamism that is already intrinsic to it. ${ }^{12}$ Nonetheless, Herder's God is an important turning point in the history of Spinoza interpretation. The only prior text to take Spinoza seriously (and which was widely read) was Jacobi's afrorementioned 
Doctrine of Spinoza. Prior to that, Spinoza's texts had been discussed, by people who had mostly never read them, for the sole purpose of denouncing them as atheistic, materialistic, and absurd. Jacobi brought Spinoza into the intellectual mainstream, but his interpretation is selective, limited, and biased. Herder is the first to acknowledge that the anti-Spinozism of the previous hundred years had been historically determined and that much of value could be found in the texts themselves.

Importantly, Herder initiates the tradition of understanding Spinoza's substance as dynamic being, the tradition that continues to dominate European interpretations of Spinoza today. He sees that the self-causing, necessarily existing substance of Spinoza's Ethics is not a static thing, but the power of a being which immanently causes its modes in the same sense in which it causes itself. Particular things are 'in' God in that they are ontologically dependent on God, not as the products of God's creation, but as inherent effects of God's immanent causality. The universe is the ongoing active causation of effects that remain part of their cause. Combining this interpretation of Spinoza with his own doctrine of organic force, Herder substitutes for Spinoza's 'God' the term 'Divine Power'. ${ }^{13}$ He stresses that Spinoza's equation of God with Nature does not imply atheism, since if Divine Power is active in all things, we cannot fail to know it.

We do not know what power is, or how power works. Still less do we know how the Divine Power has produced anything, and how it imparts itself to everything according to its nature. However, that all things must depend upon one self-dependent nature, in their existence, their relationships, as well as in every expression of their powers, no consistent mind can doubt. ${ }^{14}$

Herder disapproves of Spinoza's claim that God consists of an infinite number of attributes, of which only two, thinking and extension, are possible objects of human knowledge. Had Spinoza been writing after the discovery that matter is made up of forces, Herder decides, he would not have needed to posit infinite unknowable attributes, or insist on their absolute distinction. Spinoza would have understood that Divine Power expresses itself not in infinite unknowable ways, but rather through infinite forces, all of which are discoverable through the sciences. With hindsight, he suggests, we should reject the mysterious metaphysical aspects of Spinoza's universe, and interpret it as an infinite material dynamism generated by Divine Power. That enables us to combine a thoroughgoing naturalism with a kind of theism, while staying true to the Kantian requirement that we remain within the realm of objects of possible knowledge. Herder therefore transforms Spinoza's dictum that God is infinite attributes expressed in infinite ways into the doctrine of dynamic pantheism: 'the Deity reveals Himself in an infinite number of forces in an infinite number of ways. ${ }^{, 15}$

Because God is knowable nature, Herder argues, we can discover much more about the universe, and God, than Spinoza supposed. Empirical natural science is a method for gaining understanding of all possible universes, because all consist of material forces that can be known, and that make Divine Power known to us.

In all universes [God] reveals Himself through forces. Furthermore this infinity of forces in God which expresses His essence, has no limits whatever, although it reveals the same God everywhere. Thus, 
we must not enviously inquire of any other universe how the Deity has revealed Himself in it. Everywhere it is the same as here. Everywhere organic forces alone can be active, and every one of them makes attributes of an infinite God known to us. ${ }^{16}$

God expresses itself as Divine Power through the existence and changes of the universe, all of which are in God. Herder argues that belief in this God is not inconsistent with Christian beliefs and morals. After all, St. Paul meant something similar when he said 'In Him we live and move and have our being', as Spinoza himself noted. ${ }^{17}$ As the self-sufficient original force generating all things, God is not an 'abstract, lifeless deduction from the world' but a living being with infinite powers of thought and action.

Herder argues that Spinoza must therefore have accepted that God was not only supremely active but also supremely wise, and therefore that God's power was not that of blind necessity but of purposive design. Spinoza explicitly denies that God operates according to purposes. ${ }^{18}$ But Herder argues that Spinoza reached the wrong conclusion about God due to his mistaken distinction of thought from extension. Had Spinoza rejected the idea of infinite distinct attributes and accepted that minds and matter are products of a single attribute of force, he would not have needed to distinguish God's thought from his productive activity, or to deny that God's thought could direct material production. Understood as Divine Power, God's wisdom and productivity are seen to be one and the same, and the universe is seen to progress according to 'intelligent necessity'. ${ }^{19}$ That God does not make choices does not preclude his purposive action: the necessity of God's activity reveals the perfection and absolute wisdom of what he creates. So, while Spinoza may deny final causes on the level of individuals and species, Herder claims, he affirms that the whole universe is intelligently designed towards its own perfection. Acting of necessity and acting for the sake of an end are compatible, and so, therefore, are scientific naturalism and faith in a wise creator.

Insofar as Herder's God is an interpretation of Spinoza, it is riddled with problems. But God is much more than this, for - however unconvincingly - it sets out to use Spinozism to solve problems that Kantianism had, as yet, been unable to solve. ${ }^{20}$ Not only does Herder argue that Spinoza provides a way of reconciling science and faith; he argues that Spinoza makes mechanistic accounts of nature compatible with teleological ones. Furthermore, he suggests that by keeping all being - nature, God and human minds - strictly within the realm of organic force and possible knowledge, his de-metaphysicized Spinozism is more Kantian than Kant himself. It strives to overcome the problems of the first Antinomy without recourse to noumena, by arguing that the first, intentional cause is immanent to nature; it addresses the problem of accounting for natural difference simply by endowing organic force with divine purposiveness. Implausible though it is, Herder's God seemed to imply that if Kantians adopted its dynamic pantheism, they could combine naturalism with a wellgrounded belief in God, avoid positing a noumenal realm, and ground morality in the wise organization of the perfect universe.

\section{Kant's critique of Herder's Spinozism}


Kant had been antagonistic to Herder for some time, but the publication of God must have been particularly galling. Here was Herder sweeping through problems that had occupied Kant for years, the problem of reconciling mechanism with teleology foremost among them. In 1789 Jacobi sent Kant a copy of the second edition of his own Doctrine of Spinoza, which now included two supplements criticizing Herder's God. Specifically, Jacobi argued that God could not be both intelligent and impersonal, as Herder claimed. If Spinoza's God was an impersonal force, it must also be a power of blind necessity, with which teleology could not be reconciled. ${ }^{21}$ Jacobi's supplement on Herder was well timed for Kant, who was finishing the Critique of Judgment. Jacobi denies 'that there can be an in-between system [...] between the system of final causes and the system of purely efficient ones', but suggests that a teleological system could include mechanistic causation, as long as God had intellect and will as his highest powers. ${ }^{22}$ Kant, in the midst of developing a similar position, wrote to Jacobi on August 30 of that year to thank him for his 'handsome book on Spinoza's theory.'

You have earned distinction, first of all for having clearly presented the difficulties of the teleological road to theology, difficulties that seem to have led Spinoza to his system. To dash with hasty, enterprising steps toward a faraway goal has always been injurious to a thorough insight. He who shows us the cliffs has not necessarily set them up, and even if someone maintains that it is impossible to pass through them with full sails (of dogmatism), he has not on that account denied every possibility of getting through. ${ }^{23}$

The two systems of mechanism and teleology are the 'cliffs' to which Kant refers. The difficulty of upholding both at once led Spinoza to deny teleology and an intentional God altogether. Herder's attempt to pass between the cliffs with teleological Spinozism was doomed to fail, because he dogmatically asserted theoretical knowledge of God. But, with 'the compass of reason', Kant says, such passage is not impossible. He approves of Jacobi's refutation of the 'syncretism' of Spinozism and Deism in Herder's God, noting that syncretism is usually based on insincerity, a quality 'especially characteristic of this great artist in delusions'.

This was not the first time Kant had attacked Herder for his 'artistic' method. Four years earlier, Kant had been invited to review Part One of Herder's Ideas in the Allegemeine Literatur-Zeitung. He dismisses Herder as an eloquent lightweight whose assimilation of material from across the arts and sciences renders his work exempt from ordinary standards of judgment. He attacks Herder's method which substitutes for logical precision, careful distinctions and consistent principles 'a cursory and comprehensive vision and a ready facility for discovering analogies. ${ }^{24}$ Herder is an enthusiast who ought to 'curb his lively genius', and the Ideas a work of poetic imagination with little philosophical or scientific merit. Especially troubling to Kant is Herder's constant appeal to organic force, and his claim to have inferential knowledge of it. Explaining natural organization through organic force is 'the author's attempt to explain what is not understood in terms of what is understood even less'. ${ }^{25}$ Even worse, with his claim that organic force is known only from its effects, Herder transcends the limits of possible experience. Despite Herder's claim to set aside all metaphysics, he ends up dogmatically postulating a metaphysical entity, organic force, as the explanandum of the entire system. 
Herder's attempt to explain natural diversity through the purposiveness of organic force cannot work either. For, Kant says, the notion that a single organic force could produce every individual difference in nature is neither verifiable by science, nor comprehensible by reason.

[That] the unity of organic force which, as an autonomous formative principle in relation to the diversity of all organic creatures and subsequently as the producer of various kinds of effect appropriate to the variety of these organisms, supposedly constitutes the entire difference between the various genera and species, is an idea which lies wholly outside the field of scientific observation. It belongs to purely speculative philosophy; but even in the latter, if it were once to gain admission, it would cause much havoc among previously accepted concepts. ${ }^{26}$

Kant praises Herder for addressing the problem of natural diversity, but adds that failure is to be expected in this endeavour. 'The mysterious obscurity in which nature itself has concealed its organic functions [...] bears some responsibility for the obscurity and uncertainty' of Herder's book. ${ }^{27}$ Nature is probably too heterogeneous for its genesis as a whole to be explained in naturalistic terms, he says; an obscure, dogmatically asserted concept of organic force certainly wasn't going to solve the problem.

In 1787, then, Kant and Herder were working on the same problem: how could mechanism be reconciled with teleology, in order to account for the possibility of organic nature? Herder had offered his concept of purposive organic force, now redeveloped through Spinozism and repackaged as Divine Power. Kant, however, believed that the purposiveness of nature had to be a feature of judgment, the core conviction of the third Critique. It is in the Critique of Judgment, therefore, that Kant's critique of Herder achieves full expression. ${ }^{28}$ Sections 72 and 73 of the Critique of Teleological Judgment are dedicated to demonstrating that neither Herder's hylozoism, nor Spinozism proper, can explain the purposiveness manifested by organisms (or 'natural purposes', as Kant calls them). Section 85, 'On Physciotheology', denies that Herder's Spinozism can be a basis for faith or morality. But why was it so important to Kant that mechanism and teleology be reconciled in exactly the right way, such that Herder's God had not only to be rejected, but utterly repudiated?

First, Herder poses the problem of mechanism and teleology in the wrong way. The question is not whether nature itself is mechanistic, teleological, or both; it is how we are to judge an organized being in terms of two seemingly conflicting principles. This is how Kant introduces the Antinomy of Judgment. ${ }^{29}$ The thesis and antithesis of the antinomy represent the understanding's demand that all natural beings be judged possible in terms of mechanical laws, and reason's requirement of the law of final causes in our judgment of certain products of nature. The antinomy is one of judgment, between two regulative principles for the investigation of nature. Kant shows that if these were converted to constitutive principles concerning the productive ground of nature, we would end up with an antinomy of reason. That is the kind of antinomy found in the first Critique; were it to be posed, and resolved, along 
the lines of the first Critique, we would arrive at a regulative idea of reason for considering the productive basis of nature in general. But the problem in the Critique of Judgment is how to judge a specific object, an organism, in terms of two conflicting principles: mechanism and teleology. If we employ both principles, then we judge the same object both as fully necessitated through mechanical laws and as contingent in respect of those laws. Judgment cannot be guided by both principles simultaneously concerning the same object unless the principles are reconciled. ${ }^{30}$ The antinomy does not concern whether or not there is a non-mechanical productive cause in nature, but whether judgment is to be guided by the law of mechanistic necessity or the principle of purposive contingency. Herder's concept of Divine Power is a red herring, for even if Herder is right that the world is produced by Divine Power, we cannot know that it is, and the antinomy of judgment remains.

It is around this antinomy that Kant's worry about Spinozism emerges. For if Kant cannot reconcile the two principles, there remains a loophole through which a Kantian account of nature can be combined with Spinozism. Kant had argued, in the first Critique, that all things must be judged to be governed by the mechanical laws constitutive of phenomenal nature. But, as McFarland puts it, Kant 'did not prove that we must adopt this view of nature as the sole methodological principle in our physical investigations', ${ }^{31}$ Kant has not demonstrated that mechanical laws are the only way in which nature can be judged, leaving the way open for certain positions that are not incompatible with the arguments of the Transcendental Analytic. An adherent to Kant's first Critique could well believe that we must judge nature to be fully determined through mechanical laws down to its most specific elements, even though we may never discover what those infinitely specific laws are. On this view, contingency in nature is an illusion that indicates the limitations of our understanding in its specification of the laws of nature. A Kantian could embrace Spinoza's doctrine that nothing in nature is contingent, and that 'contingency' names our incomplete understanding of the necessary determination of a thing.

The Critique of Judgment intends, among other things, to reject this kind of deterministic Kantianism, for its consequences are dire. If everything in nature must be judged to have been necessitated through mechanistic laws, then the general laws of nature must be specified down to the most minute details. Laws would be so particularlized and heterogeneous that they would cease to be universal, threatening the possibility of natural science. But worse, the determinist scenario makes freedom impossible. There is no 'room' for the effects of noumenal free causality to be brought about in phenomenal nature. The gulf between the domain of nature and the domain of freedom remains unbridgeable, and the possibility of achieving our final purpose in nature is denied. On this account, free causality cannot be the real driver of reason, but is merely a useful fiction, as it is for Spinoza. And then the Kantian case for morality and rational faith in God falls into serious difficulty. Deterministic Kantiansim seems to end up in Spinozism, positing an infinite number of heterogeneous natural laws, denying contingency in nature, and claiming that freedom is imaginary.

The worry, then, is that a certain kind of Kantian could simultaneously hold Spinozistic views about nature, and that the first Critique did nothing to dispel those views. Herder's God had given a focus to young minds influenced by both Kant and the Spinoza-revival of the $1780 \mathrm{~s}^{32}$ The third Critique needed to show that these 
positions were not compatible, and that one could not be both a Kantian and a Spinozist unless one wanted to give up natural science, morality, and rational faith altogether. All of these concerns come to a head in the Antinomy of Judgment. The resolution of the antinomy, the defence of natural contingency, and the refutation of Spinoza are therefore central to the Critique of Judgment, as Zammito and Allison stress. $^{33}$

The presentation of the Antinomy is followed by Kant's discussion of four systems concerning the purposiveness of nature, identified according to two sets of criteria. First, are purposes in nature real and intentional, or ideal and unintentional? Second, what accounts for the purposive form manifested by organisms: physical or hyperphysical causes? Four dogmatic doctrines emerge: ancient materialism (idealist about purposes and physicalist about causes), Spinozism (idealist about purposes and hyperphysicalist about causes), hylozoism (realist about purposes and physicalist about causes), and theism (realist about purposes and hyperphysicalist about causes). While Kant argues that none of these systems explains purposiveness, the purpose of the section is primarily to refute hylozoism and Spinozism. Hylozoism posits an intentional cause to account for the production of natural purposes, but fails because it locates intentions in the life of matter. ${ }^{34}$ For Kant, the concept of a living matter is contradictory. Kant's definition of life, the ability of a being to act in accordance with representations and desires, excludes material nature. ${ }^{35}$ While human beings have life by virtue of their supersensible freedom, natural purposes can only be said by analogy to have life, based on their seemingly purposive organization. ${ }^{36}$ 'We cannot even think of living matter as possible. The very concept of it involves a contradiction, since the essential character of matter is lifelessness, inertia. ${ }^{37}$ Hylozoism proper, then, cannot stand. As for the closely related idea that matter is endowed with life by organic force 'and that nature as a whole is thus an animal ${ }^{38}$, its adherents (i.e. Herder) claim that the life principle can be inferred only from empirical observation of the natural purposiveness that is supposed to be explained by the life principle. This circular explanation, which Kant had similarly criticized in his review of Herder's Ideas, not only invents an illegitimate metaphysical principle; it fails to explain teleological judgment.

As for Spinozism, Kant argues that Spinoza's system fails to explain teleological judgment for three interrelated reasons. ${ }^{39}$ First, by claiming that particular things inhere in God, Spinoza denies that there is a causal relation between God and natural beings. Spinoza, on Kant's view, confuses the internal relation of substance to accident with the external relation of cause to effect; the immanent relation between substance and its modes precludes it being also a causal relation. If natural purposes are mere accidents inhering in substance, they cannot be considered products, either of nature or of intentional design. Second, Spinoza denies that there is contingency in nature, and therefore deprives us of our ability to judge nature to have the 'unity of purpose' required for our concept of purposiveness. This leaves no basis on which to judge nature as purposive or intentionally produced. Thus, third, Spinoza's substance has neither intentionality nor understanding. Substance produces natural forms through blind natural necessity, and thus in Spinoza's system, all of nature must be judged according to necessary mechanical laws. Spinoza's God, then, despite its unity, can explain neither the purposiveness of natural forms, nor our idea of purposiveness. Unless it meets the condition of external intentional causation, the unity of Spinoza's God can be nothing more than natural necessity, and our 
representation of its ontological unity cannot give rise to any idea of purposiveness. So Spinoza's account fails, both as an explanation of purposes in nature and as an explanation of teleological judgment. ${ }^{40}$

Kant's assessment of Spinoza is quite unfair, not least in that he ignores Spinoza's own critique of teleological judgment in the Appendix to Part I of the Ethics. If Kant is legitimately to compare his own account of purposiveness with Spinoza's, he ought to address Spinoza's explanation of our judgment that nature is purposive. Instead, Kant attacks Spinoza's view that substance is, in itself, neither contingent nor intentional, and becomes a victim of his own antinomy. We will not focus on the shortcomings of Kant's criticism of Spinoza here, however. What Kant finds objectionable in Spinoza's God is, first, that it causes its modes immanently, not externally; and second, that it lacks intentions and will, thus depriving nature of contingency and failing to ground teleological judgment. On Kant's view, then, neither Spinoza's substance, nor Herder's organic force, can account for natural purposes.

The question [of natural purposes] remains absolutely unanswerable (for our reason) unless we treat it as follows: we must think of that original basis of things as a simple substance; the quality that enables this substance to give rise to the specific character of the natural forms based on it, namely, their unity of a purpose, we must think of as its intelligence; and the relation of this substance to those natural forms we must think of as a causality. ${ }^{41}$

Herder is therefore wrong to think of God as being equivalent to nature, and knowable through scientific investigation, for that conception of God can ground neither teleological judgment nor faith. Kant's critique of physicotheology in section 85 of the Critique of Judgment aims to show that the Spinozism of Herder's God cannot ground faith. Physicotheology, defined as 'reason's attempt to infer the supreme cause of nature, and the properties of this cause, from the purposes of nature (which we can cognize only empirically)', cannot provide a basis for theology, because all its inferences to prior causes remain immanent to nature. ${ }^{42}$ A concept of a supreme intelligent cause of the world, if it is to be determinate and thereby theoretically or practically useful, depends on the determinate idea of a final purpose of nature. But physicotheology cannot even inquire into that idea, since the basis for the existence of nature must be sought outside nature. ${ }^{43}$ Herderian Spinozism might be useful for scientific speculations, and it induces us to look for a theology, 'but it cannot produce one'. ${ }^{44}$

In case his readers hadn't yet been persuaded away from Spinozism, Kant adds an unsubtle warning about the life of the Spinozist. Someone who wants to be good but does not believe in God or providence - 'Spinoza, for example' - will be unable to achieve his moral purposes. ${ }^{45}$ His failure will be directly related to his inability to see the harmony between those purposes and the laws of nature. As a result, his moral aims will be meaningless, his life purposeless, his experiences governed by despair at the disorder of the world. Worse, he will see himself and his fellow humans reduced to their materiality, subjected to 
all the evils of deprivation, disease, and untimely death, just like all the other animals on the earth. And they will stay subjected to these evils always, until one vast tomb engulfs them one and all (honest or not, that makes no difference here) and hurls them, who managed to believe they were the final purpose of creation, back into the abyss of the purposeless chaos of matter from which they were taken. ${ }^{46}$

Kant's apocalyptic vision of the meaningless life and painful death of the Spinozist is a stark warning not to reject faith in the transcendent God for the fanaticism of immanent force.

\section{Kant and Spinozism in the Opus Postumum}

We return, then, to the Opus Postumum, and the question of Kant's mysterious references to Spinoza. The Opus Postumum arguably contains a great deal of Spinozistic thinking. As I indicated earlier, Kant's ether proofs attempt to demonstrate that all possible experience is a continuum of forces that is both material and transcendental. Everything that can appear in space and time has its complete explanatory ground in the ether: Kant sometimes calls it 'space as an object of sense'. ${ }^{47}$ The closest approximation to this idea in Spinoza is what he calls 'the face of the whole universe ${ }^{, 48}$, the infinite expression of God in the attribute of extension, which can be understood as the infinite dynamical continuum of physical being. Herder's universe is really a variant of this 'face'. Kant's ether resembles this concept too: it is a single dynamical reality responsible for the existence and determination of physical beings. It is not a transitive, external cause of its effects, but rather, as an oscillating field of force which expresses individual bodies, it is those bodies, which it produces immanently. Indeed, Kant occasionally refers to the ether in Spinozistic terms: he remarks that the ether 'contains the One and All of outer sense-objects', for instance, employing a key phrase of the German neo-Spinozists. ${ }^{49}$

Given Kant's apparent conversion to a Spinozistic concept of nature, we might assume that his remarks on Spinoza reveal an affinity that he had only recently noticed, or could only lately admit. Edwards, for instance, argues that Kant casts Spinoza in a positive light in the Opus Postumum, ${ }^{50}$ a more attractive and plausible reading than Allison's limited view that Kant intends nothing towards Spinoza beyond his usual accusation of Schwärmerei, fanaticism. ${ }^{51}$ However, I think both are mistaken to believe Kant is referring to Spinoza at all in the Opus Postumum. Kant's remarks on Spinoza refer to Herder, and the influence Herder's Spinozism increasingly had on young transcendental idealists such as Schelling. This is also the view taken by Guyer, who argues that Kant names Spinoza to emphasize the difference between his own theory and the Spinozism of Schelling and his followers. ${ }^{52}$

To see why this is so, let's turn to Kant's remarks on Spinoza. They occur exclusively in the latest sections of the Opus Postumum, those written in 1800-01..$^{53}$ There are two focuses of Kant's interest: Spinoza's notion that 'we intuit ourselves in God', and, more puzzlingly, 'Spinoza's transcendental idealism'. These ideas are linked together, as if Spinoza's transcendental idealism is supposed to consist in his belief that we intuit ourselves, and all things, in God. So, for instance, we have the enigmatic comment: 'According to Spinoza's transcendental idealism, we intuit ourselves in 
God'54 and, several pages later, 'Spinoza's idea of the highest being - of intuiting all supersensible beings in God. Moral-practical reason. Transcendental idealism' ${ }^{55}$

Various explanations have been tentatively put forward for these remarks, from the view that Kant mistakenly wrote 'transcendental idealism' when he meant to castigate Spinoza's dogmatic idealism, ${ }^{56}$ to the claim that Kant actively sought to integrate Spinozism into a new variant of transcendental idealism. ${ }^{57}$ What seems clear is that Kant has latched on to an idea which, rightly or wrongly, he associates with both Spinoza and transcendental idealism. That idea is that we intuit the supersensible aspects of ourselves - our moral-practical reason - as being in God, a fact that enables us to connect our being in the world with our moral aims and faith. This is an old idea adapted to the new language of the Opus Postumum. Whereas the three Critiques taught us that humans are objects of both theoretical and practical knowledge appearances with roots in the supersensible - the Opus Postumum tells us that we are beings of ether and beings of God. As material bodies, we are part of nature, and as moral persons, we are part of the supersensible realm of God. Perhaps Kant thinks that Spinoza understood this essential point, but made the mistake of claiming that nature and God are one.

Indeed, the necessary distinctness of God and the world is a strong theme in this section. Man is the being who connects the two, by virtue of his personality, his ability to know and posit his existence as a moral being with free will.

Man, as animal, belongs to the world, but, as person, also to the beings who are capable of rights - and, consequently, have freedom of the will. [...] God, the world, and I: the thinking being in the world who connects them.

God and the world are the two objects of transcendental philosophy; thinking man is the subject, predicate and copula. The subject who combines them in one proposition. These are logical relations in a proposition, not dealing with the existence of objects, but merely bringing what is formal in their relations of these objects to synthetic unity. God, the world, and I, man, a world-being myself, who combines the two. ${ }^{58}$

There are many passages like this one in the final sections of the Opus Postumum. Many others insist that God is the world's author, not its inhabitant, and is definitely not a world-soul. ${ }^{59}$ As ever, Kant does not claim the necessary existence of God or freedom, but rather the necessity of assuming them for the unity of transcendental philosophy. God is a rational ideal that man brings to the world in order to explain it and to understand it as a suitable arena for moral action.

There is another angle to Kant's remarks on Spinoza. Kant believes that Spinoza understands space to be in God, and thus any outer experience amounts to intuiting things in God. ${ }^{60}$ Kant seems to indicate that, since God functions as a kind of formal condition of possible experience for Spinoza, Spinoza is more of a transcendental idealist than those naturalists for whom 'what matters is only the lawlike connection of appearances'. ${ }^{1}$ Perhaps this explains Kant's remark that 'the spirit of man is Spinoza's God (so far as the formal element of all sense-objects is concerned) and transcendental idealism is realism in an absolute sense'. ${ }^{62}$ That is, for Spinoza, space 
is in God, and so God, existing as the spirit of each man, provides the formal element of sense-objects. But a variant of transcendental idealism that gives God this role would be transcendental idealism 'in an absolute sense': it would substitute for subjective formal conditions absolute formal conditions. That kind of transcendental idealism would be realism. So, a transcendental idealist who maintains that space (or nature, or ether, or organic force) is 'in God', is really a metaphysical realist. 'Spinoza's transcendental idealism, taken literally, is transcendent' ${ }^{63}$ A Kantian transcendental idealist does not hold 'that we intuit in the deity, as Spinoza imagines', but rather that human beings bring the idea of God into nature. ${ }^{64}$

The purpose of Kant's Spinoza references is therefore his ongoing critique of Herderian Spinozism. It is particularly important that Kant revives this critique, since the problem that had led Kant to refute Herderian Spinozism in the Critique of Judgment had raised itself again: it appeared to be possible to hold elements of transcendental idealism and Spinozism simultaneously. Kant may have thought he had refuted Spinozism in his earlier text, but clearly not convincingly enough for young thinkers to abandon dynamic pantheism. By 1800, Kant had seen the rise of 'refined Spinozism' and its development through Naturphilosophie in the first texts of Schelling. Kant connects Schelling to Spinozism ${ }^{65}$, and cites a review of his System of Transcendental Idealism ${ }^{66}$, in which Schelling is named as Kant's greatest representative, extending Kantian idealism in exciting new directions. In these pages Kant frequently names G. C. Lichtenberg, who was positive about both Kantian idealism and 'refined Spinozism'. ${ }^{67}$ In other words, the latest sections of the Opus Postumum indicate not a new interest in Spinoza, but the resurgence of Kant's concern over those who wanted to fuse transcendental idealism with Spinozism.

Moreover, Kant had just attempted to demonstrate the necessary existence of ether, which bears a striking resemblance to similar ideas in Spinoza, Herder, and Schelling. If the ether proofs were to be published as part of Kant's 'Transition from the Metaphysical Foundations of Natural Science to Physics' (and it seems that Kant did have some of this section copied out in preparation for publication), he would need to distinguish his account of ether sharply from those other accounts of unified dynamical nature. He does this through his insistence that ether is not as unified as those other accounts. It explains material nature only, and cannot explain natural purposes. The unity of purpose that Kant found lacking in Spinoza's substance is equally lacking in his own dynamical ether, meaning that ether cannot explain purposiveness in nature. Nor does Kant intend it to: the admission that ether produces purposively would be to capitulate to hylozoism. Organic nature requires 'an immaterial principle, possessing an indivisible unity in its power of representation'. ${ }^{6}$ God cannot be grounded in ether, for God is not continuous with nature or a worldsoul inhering in it. Kant's ether is strictly distinct from God, purposes, and freedom, and it is that point that Kant needs to stress in order to distinguish his view from Herderian - or, now, Schellingian - Spinozism.

This is the context for Kant's Spinoza comments, and, while they are undoubtedly cryptic, their purpose seems to be again to make Spinozism the foil to Kant's own view that God must be thought as the external, intelligent, and purposive creator of the world. If we fail to think God in that way, and if we fail to understand ourselves as the 'hinge' between God and the world, then we resign ourselves to a world constituted and explained exclusively by forces, a world in which morality and faith 
are impossible. In 1800, Kant needs to show that science and faith are compatible without being collapsed together, and that if purposes are to be part of our judgments of nature, God and the world must be understood as transcendent, intentional cause and separate effect. Kant continues to believe that science and faith, mechanism and teleology, can be reconciled only if Spinozism is put to rest.

Whether one accepts this interpretation depends, to a large extent, on whether one sees the Opus Postumum as a whole as continuing, or disrupting, Kant's earlier conception of transcendental idealism - the primary question governing studies of this peculiar text. If the Opus Postumum marks a continuation of the ideas of the three Critiques, then I think we must conclude, as Guyer does, that Kant names Spinoza in order to reject him. If the Opus Postumum is taken to disrupt the critical system and push it in a new direction, then perhaps Kant uses Spinoza to signal his approval of Schelling, as Edwards argues, or his readiness to move beyond the anti-hylozoism of the third Critique, as Toscano suggests. I am remaining agnostic on this question for now. The rejection of Herder's Spinozism seems to me the right context in which to address Kant's late remarks on Spinoza. We can then turn to the much more interesting question of whether Kant reiterates that rejection, or recants it.

\footnotetext{
${ }^{1}$ Immanuel Kant, Opus Postumum, ed. Eckart Förster, trans. Förster and Michael Rosen (Cambridge: CUP, 1993). References will state the pagination in both the Akademie edition and the English translation. The Opus Postumum contains texts written between roughly 1796 and 1803, some of them notes and fragments, others coherent drafts towards what Kant apparently intended to be a 'Transition from the Metaphysical Foundations of Natural Science to Physics'. For information on the dating of texts in the OP, see Förster's introduction.

${ }^{2}$ Immanuel Kant, Opus Postumum, 21:229, p.76.

${ }^{3}$ See Immanuel Kant, Metaphysical Foundations of Natural Science, trans. James Ellington, in Immanuel Kant, Philosophy of Material Nature, ed. Ellington (Indianapolis: Hackett, 1985).

${ }^{4}$ Immanuel Kant, Critique of Pure Reason, trans. Norman Kemp Smith (London: Macmillan, 1929), B145.

${ }^{5}$ I have written on Kant's ether in Beth Lord, 'The Virtual and the Ether: Transcendental Empiricism in Kant's Opus Postumum', Journal of the British Society for Phenomenology 39:2 (2008). For other positions see Eckart Förster, Kant's Final Synthesis (Cambridge, MA: Harvard UP, 2000); Jeffrey Edwards, Substance, Force, and the Possibility of Knowledge (Berkeley: University of California Press, 2000); Paul Guyer, Kant's System of Nature and Freedom (Oxford: OUP, 2005); Michael Friedman, Kant and the Exact Sciences (Cambridge, MA: Harvard UP, 1992); and Alberto Toscano, The Theatre of Production (Basingstoke: Palgrave, 2006).

${ }^{6}$ Immanuel Kant, Opus Postumum, 22:547, p.85.

${ }^{7}$ For more on the pantheism controversy and the intellectual climate in Germany in the 1780s, see Frederick C. Beiser, The Fate of Reason: German Philosophy from Kant to Fichte (Cambridge, MA: Harvard University Press, 1987), and John H. Zammito, The Genesis of Kant's Critique of Judgment (Chicago: University of Chicago Press, 1992). I have drawn on these books extensively in this paper. ${ }^{8}$ Johann Gottfried Herder, Ideas for a Philosophy of the History of Mankind, in J.G. Herder on Social and Political Culture, trans. and ed. F. M. Barnard (Cambridge: CUP, 1969). References are to this edition.

${ }^{9}$ Johann Gottfried Herder, Ideas for a Philosophy of the History of Mankind, p.283.

${ }^{10}$ Johann Gottfried Herder, God: Some Conversations, trans. Frederick H. Burkhardt (Indianapolis: Bobbs-Merrill, 1940). References are to this edition.

${ }^{11}$ Johann Gottfried Herder, God: Some Conversations, pp.100-5.

${ }^{12}$ See David Bell, Spinoza in Germany from 1670 to the Age of Goethe (London: University of London Institute of Germanic Studies, 1984), pp.118-26.

${ }^{13}$ Johann Gottfried Herder, God: Some Conversations, p.97.

${ }^{14}$ Johann Gottfried Herder, God: Some Conversations, p.97.

${ }^{15}$ Johann Gottfried Herder, God: Some Conversations, p.103.
} 
${ }^{16}$ Johann Gottfried Herder, God: Some Conversations, p.104.

${ }^{17}$ See, Johann Gottfried Herder, God: Some Conversations, p.71, p.98, and p.113. Spinoza refers to St. Paul's phrase (Acts 17:28) as an illustration of his own doctrine of immanence in Letter 73: Benedict de Spinoza, Complete Works, ed. Michael L. Morgan, trans. Samuel Shirley (Indianapolis: Hackett, 2002), p.942. See also Kant’s reference to this remark in: Opus Postumum 22:55, p.214.

${ }^{18}$ Benedict de Spinoza, Ethics, Part I, Appendix, Complete Works, pp.238-43.

${ }^{19}$ Johann Gottfried Herder, God: Some Conversations, pp.122-24.

${ }^{20}$ For further discussion, see John H. Zammito, The Genesis of Kant's Critique of Judgment, pp.178-

247 and Frederick C. Beiser, The Fate of Reason: German Philosophy from Kant to Fichte, pp.127-64.

${ }^{21}$ Friedrich Heinrich Jacobi, Concerning the Doctrine of Spinoza in Letters to Herr Moses

Mendelssohn, in: The Main Philosophical Writings and the Novel Allwill, trans. George di Giovanni

(Montreal: McGill-Queen’s University Press, 1994), p.367.

${ }^{22}$ Friedrich Heinrich Jacobi, Concerning the Doctrine of Spinoza in Letters to Herr Moses

Mendelssohn, p.366.

${ }^{23}$ Kant to Jacobi, 30 Aug. 1789, in: Immanuel Kant, Correspondence, ed. and trans. Arnulf Zweig (Cambridge: CUP, 1999), Ak. 11:75-6.

${ }^{24}$ Kant's reviews of Parts I and II of Herder's Ideas were published anonymously in the Allgemeine Literaturzeitung of January 1785 and November 1785. They are now at Ak. 8:43-66, and translated as 'Reviews of Herder's Ideas on the Philosophy of the History of Mankind' in Immanuel Kant, Political Writings, ed. Hans Reiss (Cambridge: CUP, 1991), pp.201-20. References are to this edition.

${ }^{25}$ Immanuel Kant, Political Writings, p.209.

${ }^{26}$ Immanuel Kant, Political Writings, p.210.

${ }^{27}$ Immanuel Kant, Political Writings, p.210.

${ }^{28}$ Immanuel Kant, Critique of Judgment, trans. Werner S. Pluhar (Indianapolis: Hackett, 1987).

References to this are followed by the Akademie pagination.

${ }^{29}$ Immanuel Kant, Critique of Judgment, 5:386-9.

${ }^{30}$ See: Immanuel Kant, Critique of Judgment, 5:411-12, and Pluhar's introduction: Critique of Judgment, pp.lxxxviii-xci.

${ }^{31}$ J. D. McFarland, Kant's Concept of Teleology (Edinburgh: University of Edinburgh Press, 1970), p.120. See also John H. Zammito, The Genesis of Kant's Critique of Judgment, pp.214-227.

32 John H. Zammito, The Genesis of Kant's Critique of Judgment, pp.202-3, pp.246-7.

${ }^{33}$ See: John H. Zammito, The Genesis of Kant's Critique of Judgment, p.248, and Henry Allison, 'Kant's Critique of Spinoza', in Spinoza: Critical Assessments, vol. IV, ed. Genevieve Lloyd (London: Routledge, 2001), pp.188-212.

${ }^{34}$ Immanuel Kant, Critique of Judgment, 5:392.

${ }^{35}$ This definition of life can be found in the Critique of Practial Reason (Ak. 5:9n); Metaphysics of Morals (Ak. 6:211); Metaphysical Foundations of Natural Science (Ak. 4:544); and several places in the metaphysics lectures. See John H. Zammito, The Genesis of Kant's Critique of Judgment, pp.18992; Paul Guyer, Kant's System of Nature and Freedom, pp.96-8; and Alberto Toscano, The Theatre of Production, pp.19-84.

${ }^{36}$ Immanuel Kant, Critique of Judgment, 5:374-5.

${ }^{37}$ Immanuel Kant, Critique of Judgment, 5:394.

${ }^{38}$ Immanuel Kant, Critique of Judgment, 5:394.

${ }^{39}$ Immanuel Kant, Critique of Judgment, 5:393. For different interpretations of this material, see Henry Allison, 'Kant's Critique of Spinoza', pp.195-202; and John H. Zammito, The Genesis of Kant's Critique of Judgment, pp.251-9.

${ }^{40}$ Immanuel Kant, Critique of Judgment, 5:394.

${ }^{41}$ Immanuel Kant, Critique of Judgment, 5:421.

${ }^{42}$ Immanuel Kant, Critique of Judgment, 5:436.

${ }^{43}$ Immanuel Kant, Critique of Judgment, 5:437.

${ }^{44}$ Immanuel Kant, Critique of Judgment, 5:440.

${ }^{45}$ Immanuel Kant, Critique of Judgment, 5:452.

${ }^{46}$ Immanuel Kant, Critique of Judgment, 5:452.

${ }^{47}$ Immanuel Kant, Opus Postumum, 21:219, p.69.

${ }^{48}$ Benedict de Spinoza, 'Letter 64', Complete Works, p.919.

${ }^{49}$ Immanuel Kant, Opus Postumum, 21:586 and n, p.93.

${ }^{50}$ Jeffrey Edwards, Substance, Force, and the Possibility of Knowledge, p.186.

${ }^{51}$ Henry Allison, 'Kant's Critique of Spinoza', p.207.

${ }^{52}$ Paul Guyer, Kant's System of Nature and Freedom, pp.278-9. 


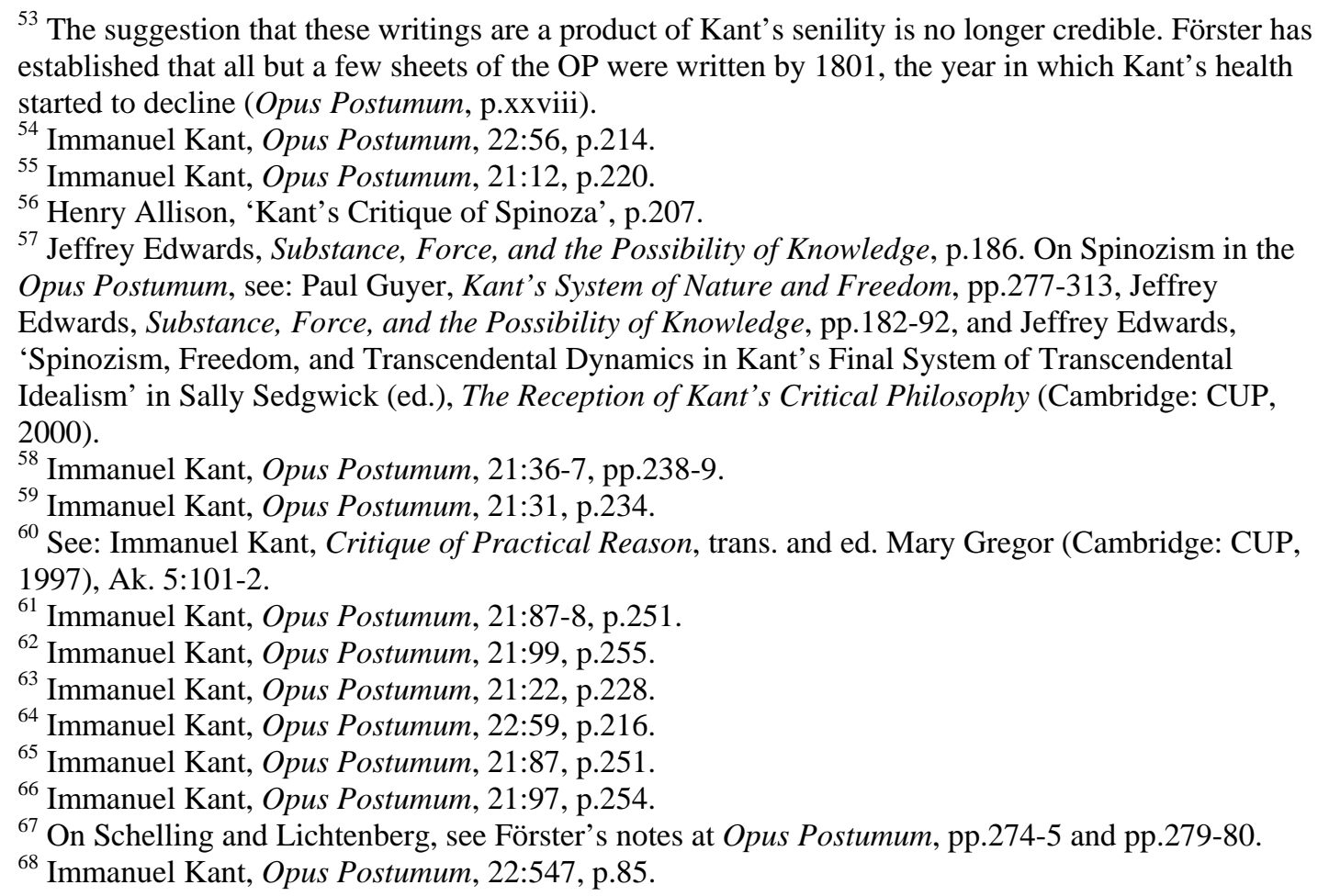

\section{Beth Lord is...}

